Jurnal Pengabdian Masyarakat Sains Indonesia

\title{
Pelatihan Mitigasi Bencana Gempa Bumi pada Siswa SDN 1 Batu Nampar Lombok Timur
}

\author{
Muhammad Ari Kusumawadi $^{{ }^{*}}$, Malahayati Rahayu Sulastri ${ }^{1}$ \\ ${ }^{1}$ Program Studi Pendidikan Fisika, FKIP Universitas Mataram, Mataram, Indonesia.
}

DOI: https://doi.org/10.29303/jpmsi.v2i1.31

Citation: Kusumawadi, M., A., Sulastri, M., R. 2020. Pelatihan Mitigasi Bencana Gempa Bumi pada Siswa SDN 1 Batu Nampar Lombok Timur. Jurnal Pengabdian Masyarakat Sains Indonesia (JPMSI). 2(1):73-77.

Article history

Received: Mei $14^{\text {th }} 2020$

Revised: Mei $18^{\text {th }} 2020$

Accepted: Mei $28^{\text {th }} 2020$

*Corresponding Author:

Muhammad Ari Kusumawadi, Program Studi Pendidikan Fisika, FKIP, Universitas

Mataram, Lombok, Indonesia. Email:

arikusuma1505@gmail.com
Abstrak: Bencana gempa bumi yang terjadi di pulau Lombok dengan kekuatan 7.0 SR pada 28 Juli dan 5 Agustus 2018 merupakan salah satu bentuk gempa dangkal akibat sesar naik Flores (Flores Arch Trust) sebagai akibat adanya desakan bawah laut benua Australia. Bencana gempa bumi yang terjadi ini membawa pengaruh yang sangat besar bagi kehidupan masyarakat. Bukan hanya kerugian ekonomi akibat hancurnya rumah-rumah warga, bangunan sekolah, pusat perbelanjaan dan terganggunya ekosistem flora dan fauna, ternyata bencana gempa bumi tersebut menyebabkan psikologis masyarakat terganggu, khususnya anak-anak. Sehingga perlu dilakukan edukasi sejak dini terkait mitigasi bencana gempa bumi untuk mengurangi dampak yang ditimbulkan baik secara moril dan materil. Pelatihan ini dilakukan di SDN 1 Batu Nampar, desa Batu Nampar, kecamatan Jerowaru, kabupaten Lombok Timur. Kegiatan pengabdian ini menggunakan pendekatan partisipatif dengan dua tahap yaitu tahap persiapan dan tahap pelaksanaan. Kegiatan ini mampu mengurangi rasa cemas berlebih pada anak-anak, meningkatkan antusiasme dan pemaham peserta didik dalam hal mitigasi bencana alam gempa bumi (MBAGB).

Kata Kunci : Pelatihan, Mitigasi Bencana, Gempa Bumi

Undang-Undang No. 24 tahun 2007 menyebutkan bahwa bencana adalah peristiwa atau rangkaian peristiwa yang mengancam dan mengganggu kehidupan dan penghidupan masyarakat yang disebabkan oleh faktor alam atau non alam maupun faktor manusia sehingga mengakibatkan timbulnya korban jiwa manusia, kerusakan lingkungan, kerugian harta benda, dan dampak psikologis. Dikutip dari BNPB 2018, bencana gempa bumi yang terjadi di pulau Lombok dengan kekuatan 7.0 SR pada tanggal 28 Juli dan 5 Agustus 2018 merupakan salah satu bentuk gempa dangkal akibat sesar naik Flores (Flores Arch Trust) sebagai akibat adanya desakan bawah laut benua Australia. Bencana gempa bumi yang terjadi ini membawa pengaruh yang sangat besar bagi kehidupan masyarakat terdampak. Bukan hanya kerugian ekonomi akibat hancurnya rumah-rumah warga, bangunan sekolah, pusat perbelanjaan dan terganggunya ekosistem flora dan fauna, ternyata bencana gempa bumi tersebut menyebabkan jatuhnya korban jiwa dan kerugian materil seperti hancurnya rumah-rumah warga, infrastruktur dan kehancuran fasilitas vital lainnya. 
Kusumawadi et al, Jurnal Pengabdian Masyarakat Sains Indonesia 2020, 2 (1):73-77. DOI : https://doi.org/10.29303/ipmsi.v2i1.31

menyebabkan psikologis masyarakat terganggu, khususnya anak-anak.

Anak-anak sebagai bagian dari masyarakat turut menjadi korban. Sebagaimana Idris (2020) menyebutkan bahwa, gempa yang terjadi di pulau Lombok menyebabkan gangguan mental serius bagi masyarakat yang dapat mempengaruhi pola kehidupan masyarakat di masa mendatang. Masyarakat selalu mengalami rasa takut setiap terdengar suara sehingga membuat masyarakat menjadi tidak nyaman (BNPB, 2018). Jika rasa cemas dan takut ini tidak segera ditanggulangi, maka akan membahayakan bagi perkembangan mental anak-anak di masa depan. Sehingga perlu dilakukan edukasi sejak dini terkait bencana gempa bumi untuk mengurangi dampak yang ditimbulkan baik secara moril maupun materil. Edukasi yang dilakukan dapat dimulai dari anak-anak sebagai kelompok rentan. Berdasarkan Undang-undang Nomor 24 Tahun 2007 tentang Penanggulangan Bencana, anak digolongkan dalam kategori rentan dikarenakan anak-anak memiliki keterbatasan pengetahuan dan kemampuan terkait mitigasi bencana.

Mitigasi bencana merupakan usaha-usaha yang dilakukan untuk mengurangi resiko bencana. Pengurangan resiko bencana gempa bumi sering disebut Mitigasi Bencana Alam Gempa Bumi (MBAGB). MBAGB merupakan langkah awal yang dapat dilakukan untuk menekan kerugian dan meningkatkan pengetahuan dan keterampilan masyarakat dalam menghadapi ancaman bahaya gempa bumi.

Pelatihan ini dilakukan di SDN 1 Batu Nampar yang terletak di kecamatan Jerowaru, kabupaten Lombok Timur, provinsi Nusa Tenggara Barat. Pelatihan MBAGB yang dilakukan berorientasi pada kurikulum MBAGB (Subagia, 2015). Kurikulum tersebut terdiri dari rumusan standar kompetensi (SK), kompetensi dasar (KD), dan indikator pencapaian kompetensi (IPK), seperti dijabarkan sebagai berikut.

Tabel 1. Standar Kompetensi dan Kompetensi Dasar Kurikulum Pendidikan Mitigasi Bencana Alam Gempa Bumi

\begin{tabular}{llcl}
\hline \multicolumn{2}{l}{ Standar Kompetensi } & \multicolumn{2}{c}{ Kompetensi Dasar } \\
\hline 1. & Memahami hakikat & 1.1 & \multicolumn{2}{c}{$\begin{array}{l}\text { Mendeskripsikan } \\
\text { hakikat } \\
\text { gempa bumi }\end{array}$} & \multicolumn{2}{c}{ gempa } \\
\hline 2. & Memahami akibat & 2.1 & \multicolumn{2}{c}{ Mendeskripsikan } \\
yang ditimbulkan & & akibat & yang \\
oleh gempa bumi & & ditimbulkan oleh \\
\hline
\end{tabular}

\begin{tabular}{|c|c|}
\hline & $\begin{array}{l}\text { e-ISSN : 2715-2537 } \\
\text { p-ISSN : 2715-2545 }\end{array}$ \\
\hline Standar Kompetensi & Kompetensi Dasar \\
\hline & gempa bumi \\
\hline \multirow[t]{2}{*}{$\begin{array}{l}\text { 3. Memahami cara } \\
\text { mitigasi bencana } \\
\text { alam gempa bumi }\end{array}$} & $\begin{array}{l}\text { Mendeskripsikan } \\
\text { cara-cara } \\
\text { penyelamatan diri } \\
\text { saat gempa bumi }\end{array}$ \\
\hline & $\begin{array}{l}\text { Mendeskripsikan } \\
\text { cara-cara } \\
\text { mengantisipasi } \\
\text { bencana alam } \\
\text { gempa bumi }\end{array}$ \\
\hline
\end{tabular}

Perumusan indikator pencapaian kompetensi berdasarkan SK dan KD tersebut seperti dijabarkan berikut.

1.1.1 Mendefinisikan gempa bumi

1.1.2 Menjelaskan peristiwa gempa bumi

2.1.1 Mengidentifikasi akibat gempa bumi

2.1.2 Menjelaskan akibat gempa bumi

3.1.1 Mengidentifikasi cara penyelamatan diri ketika gempa bumi

3.1.2 Menjelaskan cara-cara penyelamatan diri ketika gempa bumi

3.1.3 Melakukan latihan penyelamatan diri ketika gempa bumi

3.2.1 Mengidentifikasi cara-cara mengantisipasi bencana alam gempa bumi

3.2.2 Menjelaskan cara-cara mengantisipasi bencana alam gempa bumi

3.2.3 Membuat model antisipasi penyelamatan diri saat gempa bumi

\section{Metode}

Kegiatan pengabdian pelatihan mitigasi bencana alam gempa bumi (MGAGB) ini menggunakan pendekatan partisipatif yang berorientasi dalam peningkatan peran peserta didik secara langsung pada proses pembelajaran. Maka dari itu, dalam pelaksanaan program ini dibutuhkan tahapan-tahapan yang tersusun secara sistematis, yaitu:

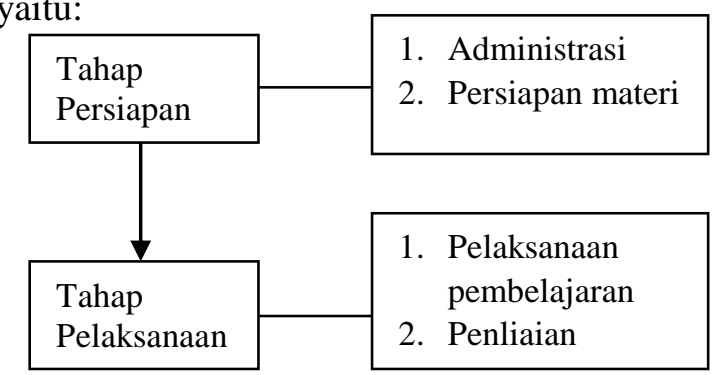

Gambar 1. Bagan Alur Kegiatan Pengabdian di SDN 1 Batu Nampar 
Kusumawadi et al, Jurnal Pengabdian Masyarakat Sains Indonesia 2020, 2 (1):73-77. DOI : https://doi.org/10.29303/ipmsi.v2i1.31

Tahap Perisiapan

Dalam tahap ini , hal-hal yang dilakukan adalah

a. Administrasi

Terdapat beberapa poin yang harus dilengkapi dalam tahap administrasi yaitu: 1) Penetapan sekolah sasaran, yaitu di SD Negeri 1 Batu Nampar, Desa Batu Nampar, Kecamatan Jerowaru, Lombok Timur, 2) Memperoleh izin pelaksanaan program pengabdian pelatihan mitigasi bencana gempa bumi dari kepala sekolah 3) Pendataan jumlah peserta didik yang akan mengikuti pelatihan.

b. Persiapan Materi dan Alat

Kegiatan pelatihan dipandu dengan unitunit pembelajaran. Ada lima unit pembelajaran yang disiapkan pada pelatihan mitigasi bencana alam gempa gempa bumi, yaitu: 1) Hakikat Gempa Bumi, 2) Akibat Gempa Bumi, 3) Cara Penyelematan Diri Saat Terjadi Gempa Bumi, 4) Cara Mengantisipasi Gempa Bumi, dan 5) Model Antisipasi Gempa Bumi. Pada pelatihan ini, hanya empat unit yang disampaikan, sementara unit ke lima tidak dilaksaan dikarenakan kendala di lapangan. Persiapan alat yang diperlukan seperti laptop, pensil dan buku.

\section{Tahap Pelaksanaan}

Kegiatan pengabdian ini melibatkan peserta didik kelas IV SDN 1 Batu Nampar yang berjumlah 25 orang. Kegiatan pertama yaitu, peserta diajak berdiskusi tentang kejadian gempa bumi, dilanjutkan dengan kegiatan mengamati gambar peristiwa yang terjadi saat terjadi gempa bumi dan diakhiri dengan kegiatan menjelaskan gambar yang dibuat di depan kelas. Kedua, peserta didik diajak berdiskusi tentang akibat gempa bumi, dilanjutkan dengan kegiatan mengamati berbagai gambar peristiwa akibat gempa bumi, dan diakhiri dengan kegiatan menjelaskan gambar yang dibuat di depan kelas. Ketiga, peserta didik diajak untuk berdiskusi tentang cara menyelamatkan diri ketika terjadi gempa bumi disertai dengan latihan penyelamatan diri dan melakukan pertolongan pertama untuk mengantisipasi jatuhnya korban jiwa. Keempat, peserta didik diajak berdiskusi terkait tempat berlindung ketika terjadi gempa bumi. Kelima, peserta didik diberikan tes tertulis dalam bentuk isian singkat.
e-ISSN : 2715-2537

p-ISSN : 2715-2545

Tabel 1: Langkah-Langkah Kegiatan Pembelajaran Tanggap Bencana Gempabumi

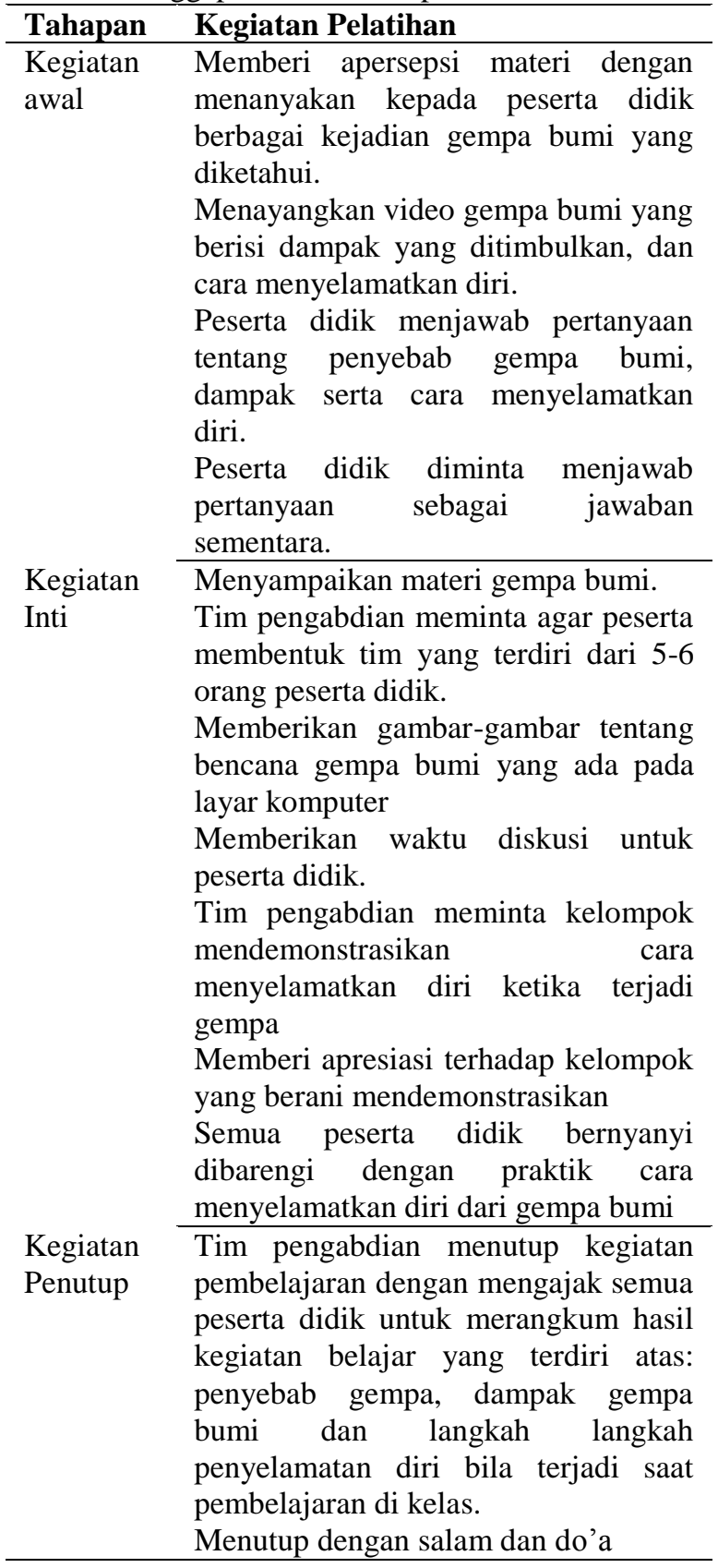

Penilaian Hasil Kegiatan

Penilaian hasil kegiatan pelatihan dilakukan dalam dua bentuk, yaitu penilaian partisipasi peserta didik dan penilain penguasaan materi yang dilaksanakan di akhir kegiatan pembelajaran. Penilaian partisipasi dilakukan melalui pengamatan, sedangkan penilaian penguasaan materi dilakukan melalui tes tertulis. Pedoman pengamatan partisipasi dan tes 
Kusumawadi et al, Jurnal Pengabdian Masyarakat Sains Indonesia 2020, 2 (1):73-77. DOI : https://doi.org/10.29303/ipmsi.v2i1.31

penguasaan materi disediakan secara terpisah. Hasil penilaian partisipasi dalam kegiatan dituliskan dalam bentuk deskripsi dengan kategori sebagai berikut.

1. Berpartisipasi cukup, apabila peserta didik mengikuti pelatihan secara penuh (dengan simbol +).

2. Berpartisipasi baik, apabila peserta didik mengikuti pelatihan secara penuh dan sesekali memberi tanggapan (bertanya atau menjawab) terhadap materi yang disampaikan (dengan simbol ++).

3. Berpartisipasi sangat baik, apabila peserta didik mengikuti pelatihan secara penuh dan beberapa kali memberi tanggapan (bertanya atau menjawab) terhadap materi pelatihan (dengan simbol +++).

Hasil penilaian penguasaan materi menggunakan skala 100 dengan keterangan sebagai berikut:

Sangat kurang $=0-20 \%$

Kurang $=21-40 \%$

Cukup $=41-60 \%$

Baik $=61-80 \%$

Sangat baik $=81-100 \%$

(Subagia, 2014).

\section{Hasil dan Pembahasan}

Berdasarkan isi materi pelatihan, hasil pengabdian berupa dua penilaian, yaitu deskripsi kualitatif hasil pelaksanaan pelatihan dan deskripsi kuantitatif pencapaian hasil tes penguasaan materi yang dilaksanakan pada akhir kegiatan.

\section{Deskripsi Hasil Pengabdian}

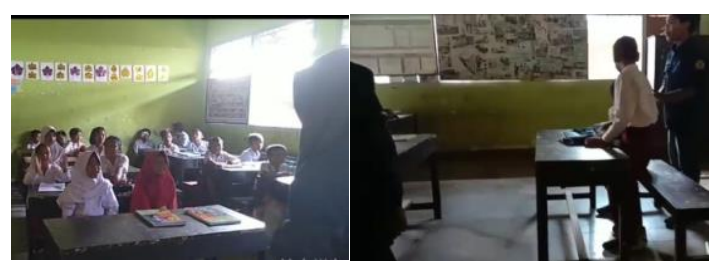

Gambar 1. (a) Proses pembelajaran di kelas (b) Pelaksanaan Mitigasi di Dalam Kelas

Pada awal kegiatan pelatihan, peserta didik tampak terlihat tegang namun dengan kegiatan yang dilakukan, peserta didik menjadi lebih menikmati dan fokus terhadap materi pelatihan yang diberikan. Materi yang disampaikan ada empat yakni; 1) Hakikat gempa bumi, 2) Dampak yang ditimbukan, 3) Langkah penyelamatan diri
e-ISSN : 2715-2537

p-ISSN : 2715-2545

saat terjadi gempa bumi, dan

4) Cara mengantisipasi kejadian gempa bumi.

Kegiatan diskusi diawali dengan penyampaian materi oleh tim pengabdian. Peserta didik dibagi menjadi beberapa kelompok dan diminta mengamati serta mendikusikan gambar tentang gempa bumi. Kemudian dua orang perwakilan kelompok mempresentasikan hasil diskusi tersebut. Kegiatan yang sama dilakukan pada materi selanjutnya. Terlihat peserta didik antusias berdiskusi dan bertanya setelah dilakukan presentasi. Tim pengabdian mengajukan pertanyatanyaan seputar materi yang telah disampaikan. Peserta didik semakin antusias setelah dikatakan bagi yang bertanya dan menjawab akan mendapatkan hadiah. Dari kegiatan pengabdian ini, tampak bahwa peserta didik sudah memiliki pengetahuan terkait cara menyelamatkan diri ketika terjadi gempa bumi. Hal tersebut dapat dilihat dari kecepatan peserta didik dalam menerima dan mengikuti petunjuk yang diberikan, misalnya ketika peserta didik dilatih untuk berlindung di bawah meja saat terjadi gempa bumi. Dalam waktu singkat peserta didik dapat melakukan hal tersebut dengan baik. Sementara itu, saat praktik pemberikan pertolongan pertama kepada korban, yang dilakukan dalam bentuk pemberian obat merah dan membalut luka, beberapa peserta masih menunjukan keragu-raguan, namun melalui bimbingan pelatih, peserta didik mampu bekerja dengan baik.

Berdasarkan wawancara yang dilakukan terhadap peserta didik secara acak, diperoleh informasi bahwa peserta didik merasa sangat terhibur dan senang dengan pelatihan yang diberikan, peserta didik menjadi tahu bahwa kepanikan saat terjadi bencana dapat membahayakan nyawa, peserta didik juga menyebutkan bahwa melalui kegiatan ini dapat meningkatkan pengetahuan dan keterampilan untuk menyelamatkan diri dan orang lain yang berada di sekitar.

\section{Deskripsi hasil Penilaian}

Penilaian hasil tes pengetahuan peserta didik diperoleh melalui uji tes tertulis dalam bentuk isian singkat yang didasarkan pada indikator pencapaian kompetensi yang telah ditetapkan. Tes ini diberikan di akhir kegiatan pembelajaran. Berdasarkan hasil tes tersebut diperoleh bahwa sebanyak $5 \%$ peserta didik mendapatkan nilai 
Kusumawadi et al, Jurnal Pengabdian Masyarakat Sains Indonesia 2020, 2 (1):73-77. DOI : https://doi.org/10.29303/ipmsi.v2i1.31

dengan kategori sangat baik (81-100), 18\% peserta didik mendapatkan nilai dengan kategori baik (6180), $37 \%$ peserta didik dengan nilai cukup baik (41$60), 26 \%$ peserta didik dengan kategori kurang (2140) dan $14 \%$ peserta didik dengan kategori sangat kurang (0-20).

Nilai ini merupakan cerminan hasil belajar peserta didik. Hasil tersebut menunjukkan bahwa akumulasi perolehan nilai peserta didik dengan kategori cukup baik, baik dan sangat baik yaitu sebanyak $60 \%$ yang berarti bahwa sebanyak $60 \%$ peserta didik telah mampu mengikuti pembelajaran dengan baik sehingga diharapkan dapat meningkatkan pemahaman peserta didik terkait bencana gempa bumi dan cara-cara mitigasi bencana gempa bumi untuk dapat mengurangi resiko yang ditimbulkan.

\section{Kesimpulan}

Kegiatan pengabdian di SDN 1 Batu Nampar, Lombok Timur sangat bermanfaat sebagai upaya menyiapkan peserta didik menghadapi bencana alam gempa bumi. Kegiatan pengabdian ini dapat meningkatkan pengetahuan dan keterampilan tentang cara menyelamatkan diri sehingga mampu menekan jumlah korban jiwa, selain itu kegiatan ini dapat mengurangi gangguan psikologis yang timbul akibat rasa takut yang berlebih dengan ancaman bencana gempa bumi dibuktikan dari hasil tes partisipasi dan tes pemahaman.

\section{Ucapan Terimakasih}

Terimakasih kami ucapkan kepada desa Batu Nampar, Kecamatan Jerowaru, Lombok Timur.

\section{Daftar Pustaka}

Ayub, Syahrial., Makhrus, Muhammad., Arduha, Jannatin., Verawati, Ni Nyoman Sri Putu., Kosim, K. 2019. Kesiapsiagaan Bencana Gempabumi di SMP Negeri 2 Mataram. Jurnal Pengabdian Magister Pendidikan IPA. (2) 1. pp. 25-31.

Farida, Meutia., Alimuddin, Ilham., Maulana, Adi., Irfan, Ulfa Ria., Jaya, Asri., Sultan, S., Kaharuddin, K., Agustinus, A. 2019. Sosialisasi Bencana Geologi dan
e-ISSN : 2715-2537

p-ISSN : 2715-2545

Mitigasinya di Sekolah Dasar Islam

Terpadu (SDIT) Ar-Rahmah Makassar. Jurnal Teknologi Terapan untuk Pengabdian Masyarakat. Volume 2, Nomor 2.

Idris, Baiq Nurainun Apriani., Istianah, I., Hadi., Irwan. 2020. Decreasing The Level of Depression for Earthquake Victims Through Counseling With a Motivational Interviewing Approach. Media Keperawatan Indonesia. Vol 3 No.1.

Republik Indonesia. 2007. Undang-Undang No. 24 Tahun 2007 tentang Penanggulangan Bencana. Lembaran Negara RI Tahun 1974. Jakarta.

Subagia, I Wayan, I G. L. Wiratma, dan I Ketut Sudita. 2014. Materi Pelatihan Mitigasi Bencana Alam Gempa Bumi Berbasis Kearifan Lokal Masyarakat Bali. Singaraja: Undiksha Press.

Subagia, I Wayan, I G. L. Wiratma, dan I Ketut Sudita. 2015. Pelatihan Mitigasi Bencana Alam Gempa Bumi pada Siswa Sekolah Dasar Negeri 1 Pengastulan Kecamatan Seririt Kabupaten Buleleng Bali. Bali: Undiksha Press. 